\author{
Małgorzata Malec Rawiński \\ Ilona Zakowicz \\ Uniwersytet Wrocławski
}

\title{
„Be like Dj Wika?” - a word about an unexpected turn of senescence
}

\author{
„Być jak DJ Wika?” - o niestereotypowym wizerunku późnej \\ dorosłości
}

Streszczenie. Wśród inspiracji, które przyczyniły się do powstania niniejszego artykułu było przekonanie, że starość „niejedno ma imię”, a precyzyjnie - że ma ona nie jeden, ale wiele wizerunków. Dostrzegana przez nas wieloznaczność, wielowymiarowość i wielokontekstowość starości stała się impulsem do podjęcia refleksji nad niestereotypowymi wizerunkami starości, wśród których za szczególnie interesujący poznawczo uznałyśmy wizerunek kreowany przez Wirginię Szmyt, znaną jako DJ Wika.

Projekt „Być jak DJ Wika?”, którego zarys przedstawiony został w niniejszym artykule, jest efektem obserwacji wzrastającej popularności Wirginii Szmyt. To ona stała się impulsem do podjęcia przez nas refleksji nad „niestereotypowymi wizerunkami starości”. Celem wspomnianego projektu było dokonanie analizy wizerunku DJ Wiki w oparciu o trzy wzajemnie uzupełniające się perspektywy: medialną, senioralną, osobistą/indywidualną. Postawione przez nas pytania badawcze skłoniły nas do zaprojektowania i przeprowadzania procedury badań jakościowych, na podstawie jakościowej analizy treści wspartej zogniskowanymi badaniami fokusowymi i pisemnymi wypowiedziami seniorów biorących udział w projekcie.

Jakościowa analiza zebranego materiału badawczego (medialne wypowiedzi Wirginii Szmyt opublikowane w postaci wywiadów w internecie, prasie, książce, dwóch zogniskowanych wywiadów grupowych (focus group interviews) przeprowadzonych wśród seniorów UTW w UWr oraz pisemne wypowiedzi uczestników projektu) doprowadziła do wielu interesujących wniosków, które zostały przedstawione w niniejszym artykule.

Słowa kluczowe: senior; starość; stereotyp; media; image.

Summary. Nowadays aging and old age is quite popular in many fields also in mass media we can see pictures of older adults who might be named non-stereotypical. The aim of the paper is to present one of the non-stereotypical picture of old age the oldest Polish DJ Wirginia Wika Szmyt. The article presents designed and conducted 
qualitative research - text analysis of collected data (many interviews, articles available online and in press about Wirginia Szmyt and biographical book DJ Wika. This is power!) and analysis of the narrations of focus group interviews of the seniors students of U3A). The aim of the research was the analysis of the interesting aspects of the three complementary perspectives: the media, the senior and individual. The article presents the results of the first stage of the project carried out oscillating around issues of nonstereotypical perception, experiencing and imaging old age.

Key words: senior; old age; stereotype; media; image.

[...] The authentic study of old age should consist of two elements: it cannot be based on stereotypes or a pejorative approach and should seek to define the meaning of the final stage of life

N. Pikuła

\section{Introduction}

Old age is usually considered a time of illness, weakness, loneliness, clumsiness, hardship and death. No wonder it is feared and popular stereotypes make it even harder to accept. Nonetheless, as difficult as it may be, old age can be a time of different shades, multidimensional, multiple-valued and multi-contextual. In our public life, there are numerous examples of people cheerfully "getting along" with their old age - some of them even came about in the social mass media and became its celebrities. One of them is a famous stylist and blogger, Krystyna Bałakier, and another is Wirginia Szmyt - better known for her stage name: DJ Wika. Originally from Warsaw, the DJ is highly esteemed among seniors, seen by them as a "great personality". She inspires, integrates the generations, breaks the stereotypes and simply impresses, as stated in her book Dj Wika Jest moc! ("DJ Wika Is Power!"), published in 2016.

Based on the social mass media sources about Wirginia Szmyt (articles, interviews, the book Dj Wika Jest moc!) and the opinions of UTA members, this paper analyses society's perception of the third age. Before any further study, however, we should explain briefly two terms appearing frequently in this paper: old age and stereotype. 


\section{Old age - multidimensional, multiple-valued and multi-contextual}

The question of old age and the place of elderly people in modern society has recently been looked at more closely not only by specialists in social sciences and humanities or medicine, but also by the mass media industry. The image of old age tends to be limited to its physical and medical aspects, but there needs to be a different, wider approach - one that reflects the whole social and individual spectrum of this period. This is an extremely important matter nowadays, given the accelerated rate of modern societies' aging and the impact that causes. Minois observes that 'Every type of socio-economic and cultural organization is responsible for the role and image of its old people' - every society creates its own image of a perfect human being that determines the perception and value of old age (1994, p. 18). As a result, "Every society has the old people it deserves" (Minois 1995, p. 17).

One, binding, way of perceiving senility does not exist; its images are very differentiated. Agedness is the most personal, individual stage of life, which means there are different styles of experiencing it, hence various approaches towards its perception. The quality of old age depends on multiple factors, either social and genetic - diet, profession, style of life, residence, medical history and political situation. It is also worth noting that the senectitude phenomenon requires a further reflection - it is too easily limited only to its biological aspect. Georges Minois, a famous French historian, seems to share this belief when he ponders about the onset of senilitywhen does a man get old? Once he reaches his fifties? At sixty? Seventy? The boundaries of old age are blurred, due to the sheer number of elements that influence them - biological, physical, psychological and social. Is a man's age the age of his body or the one in his birth-certificate? Or maybe the way other people look at us makes us old? (Minois 1995, p. 11).

The moment of retirement seems old age's most commonly accepted starting point, for it is then when a person becomes legally acknowledged as a senior (retired) person. As a consequence, for some people retirement means a decrease in social activity (e.g. dropping acquaintances with co-workers), social uselessness or at least unserviceableness and a lack of affiliation. Meanwhile, some people consider retirement a perfect moment for their own self-development, a time of satisfaction and self-fulfillment. It is "regained-tim"' they can take full advantage of by making their dreams come true, by making new acquaintances and acquiring new skills and tackling new tasks. A fine example of this attitude is Wirginia Szmyt. 


\section{Stereotype and processes that consolidate it}

Writing about the non-stereotypical we should first provide a brief explanation of what the stereotype is, what triggers and consolidates it. We often create images of old age basing ourselves on the stereotypes existing in our minds, originating from direct personal experiences or adopted. Zdzisław Chlewiński (1992) considers stereotypes to be a result of socialization and enculturation, especially during the language learning process. Language is a powerful vehicle for stereotypes, contributing to their preservation.

A crucial role in the process of the creation of stereotypes is played by the teaching of history, literature and the mass media. Language supports the formation and preservation of different stereotypes, as it is a tool that limits us, determines our actions, creates and transports popular jokes, clichés and "funny" stories that ridicule, infantilize and offend. An important role in the creation of stereotypes is also played by national symbols, behavior patterns, culture values and personal features (Nikitorowicz 2001).

We organize our reality and societies, categorizing and classifying things. Our approach towards other people is based on the general image of the group he or she belongs to - in other words, we build our opinion on inherent stereotypes or individual attributes (more or less visible). Having an established image of old age helps us in organizing reality by allocating specific attributes to a certain group of people. If we consider the autumn of life only as a time of diseases, dotage, unattractiveness and merely as a death-anticipating vegetation phase, according to the process of categorization we will perceive every senior as snappy, boring grumblers, often passive and ill. Unfortunately, we run across negative stereotypes far more often than positive ones - e.g. linking old age with experience and wisdom a result being the fear of getting old. One of the outcomes of categorization is intensification of social divisions ("us" and "them", young vs. old), which deprives a person of their individual attributes - hence social stigmatization and marginalization.

We strongly believe that the non-stereotypical images of old age in general and examples of "maverick" senior lifestyles like the one presented in this article, should be promoted - it is truly a task worth undertaking. 


\section{Methodology of the "Be like Dj Wika?" project}

The idea of the "Be like $\mathrm{Dj}$ Wika?" project originated from the study of the growing popularity of Wirginia Szmyt. Her presence has been strongly felt in the social mass media in 2016, backed up by a number of articles, interviews and TV shows that included her. This new phenomenon inspired us to study the case closer. We are both interested in gerontology, so after exchanging views on Dj Wika's strong personality and growing fame, we decided to show different ways of "getting along" cheerfully with old age and make it a case study - apart from presenting the charismatic personality of Wirginia Szmyt.

During the discussion we asked ourselves several questions, which were later put into three groups. In the first one we placed questions regarding only Dj Wika: What distinguishes Wirginia Szmyt from other seniors? Can we acknowledge her way of experiencing old age as non-stereotypical? If yes, why? Is Wirginia Szmyt breaking the stereotypes? How? What kind of a senior is Wirginia Szmyt? What is her perception among seniors?

We also considered the social perception of $\mathrm{Dj}$ Wika to be interesting, so we put her popularity in the mass media up for discussion. We were looking for the answers among other seniors, in this case the UTA members, namely to the following questions: what is their opinion about Dj Wika? Do they identify themselves with the image she represents? If positively, how? Which actions of Dj Wika are acceptable and which undesirable, in their opinion?

The third set of questions regarded $\mathrm{D} j$ Wika's image in the mass media: In what way is her image created by the mass media? Do seniors consider her presence in the mass media as important? Does Wirginia'a popularity cause a change in the perception of old age and in the way people deal with it? What would be its signs?

The above questions prompted us to carry out a quality survey, with an analysis of the content of the mass media sources and to use focus group research. The main aim of this project was to analyze the issue from three different, but complementary perspectives - the first one being the study of $\mathrm{Dj}$ Wika's image in the mass media. We conducted a qualitative research of the relevant sources - articles, interviews, comments in the social mass media websites, the book $D j$ Wika Jest moc! and Wirginia's recordings.

The second perspective: the seniors' view. The intention was to gather data for the study of how Wirginia was perceived among her co-agers. We planned and carried out two focus group interviews - in the first one, sev- 
en active members of UTA Discussion Group (managed by Ilona Zakowicz) participated. It turned out that seniors had some general knowledge about Dj Wika. Four of them follow the events occurring in Wika's life, two of them heard about her but had only very superficial knowledge from random articles and interviews. Only one person appeared to have no idea who Dj Wika was, but in the course of discussion admitted having heard about her once or twice. Before the second focus group interview the same seniors had to read the book Dj Wika Jest moc! so their knowledge about Mrs. Szmyt would be more comprehensive. During the discussion seniors shared their reflections regarding the extended interview with Wirginia Szmyt made by the authors of the book - Jakub Jablonka and Pawel Leczuk.

The third perspective: personal opinion. At this point, the previously gathered and analyzed data will be confronted with the opinions, convictions and beliefs of Wirginia Szmyt herself. A structured interview will be carried out in order to complement current knowledge with new views and interpretations, as well as to broaden the range of the analysis.

In addition we use the written statements of seniors answering the questions about Dj Wika's social activity. The survey is a valuable, in-depth addition to their previous opinions.

In this article the outcome of the analysis from the two first perspectives will be presented. The third perspective will appear later on in a separate article, as a complementary continuation of the current research.

\section{Who is DJ Wika?}

On one of the Bialystok TVP 3 websites you can read that "DJ Wika is 78 years old and a perfect ambassador of Polish seniors. She proves that old age is irrelevant when it comes to making one's dreams come true. She has been taking care of old people problems for twenty years now and organizes inter-generational dancing parties that attract a lot of her fans, both the young and the older ones. Once retired, she began to organize dancing parties for seniors - she observed the work of DJs she'd paid for before taking control of the console herself” (TVP3 Białystok, „Młodzi duchem” 2016). She started working at social evenings for seniors, and soon after in the "Bolek" pub on Pole Mokotowskie. DJ Wika has her own mixer, two laptops and a turntable, skillfully handled during inter-generational dancing parties. "She works for a number of inter-generational disco clubs in Poland, but mostly in Warsaw. She receives invitations from various clubs, also from 
abroad. Dj Wika inspires and delights with her vivacity, insatiable curiosity and a unique style” (TVP3 Białystok, „Młodzi duchem” 2016).

DJ Wika is the oldest DJ in Poland, the ambassador and originator of the Seniors Parade, organized in Warsaw. The first parade, along with the Picnic of Generations, took place on the $28^{\text {th }}$ of June, 2014. In collaboration with the Zaczyn Foundation, she organized two more parades - on 20.06.2015 and 25.06.2016. Every year more and more people join the $\mathrm{Pa}-$ rade - last year there were several thousands of $60+$ participants. It is worth noting that the Parade has gained in increasing interest for the mass media industry, thanks to DJ Wika's commitment in promoting the event on the radio and television. DJ Wika's popularity is attested by the award she won in 2014 when she became "the face of Eska TV" (Eska Music Awards). Wirgina worked for many years in special needs education and as a teacher in correction centres. She was married twice, the first time before her $20^{\text {th }}$ birthday. She had two sons from this marriage - Marek and Witold. Her second husband was a scientist and a diplomat, they met in her forties. She claims him as her inspiration and the reason she began her DJ career. DJ Wika loves animals (especially cats) and nature. She is a social activist, committed to organization of events and initiatives for old people. She founded a cabaret called "Viagra" (the name was later changed to "To i Owo"). She is very fond of facebook, almost addicted to it as she once put it, and actively participates in its virtual life.

\section{DJ Wika in the mass media}

Content quality analysis of various internet sources (articles, interviews, facebook comments) and the book DJ Wika Jest moc! provides us with several areas of Wirginia's personal life that she shares with the public. It is mostly about her job and career, home, love and the family, passion, dreams, different stages of life (youth, maturity and old age), parties, music, working as a DJ, discrimination and the rights of old people (also empowerment). Both in her book, DJ Wika Jest moc! and in several interviews she mentions the desire for love. It is an important topic, for in Poland there are still a few taboo subjects regarding old people sexuality and intimate relationships. It is worth noting that DJ Wika refers often to seniors' desire for love, friendship, acceptance, affiliation and joy - it all allow us to look at the autumn of life from a wider perspective. 
On the kobieta.wp.pl website Mrs. Wirginia says she feels her mission is to help in the emancipation of seniors, to encourage them to "be themselves" regardless of their age, to break the stereotypes and fight social stigmata: Wirginia cannot stand pigeonholing. She encourages the others, not only seniors, not to let themselves been placed in the category of "mohair", "bigot", "waiting for death" - it is a general opinion that a retired woman is a decent, respectable woman if her life is spent between the holy mass, the rosary and the cemetery. Wirginia believes that If a woman decides to put on a colorful dress instead, go to a café or attend a dancing party, her behavior arouses suspicions and uncomfortable questions. Breathing with relief, she adds: "Fortunately, this situation is changing. There are less voices saying that something is bad form. Everything is good form!" (Wawrzyńczak 2013).

The growing mass media interest in the phenomenon of DJ Wika has two dimensions: individual and social. Popularity gives her joy and satisfaction, being in a sense a crowning achievement for her track record, but on the other hand it is a kind of mission. Both Mrs Szmyt and the mass media admit uno animo that her popularity contributes to social awareness of old people's problems and needs.

An insight into Wika's speeches, especially those concerning initiatives for seniors, let us assume that Wirginia Szmyt is a woman consciously fulfilling her mission, convinced that her entertainment activities for and with seniors, supported by her popularity, will bring forward several difficult and socially awkward issues concerning the daily life of seniors (Jabłonka, Łęczuk 2016, p. 201). Moreover, DJ Wika claims that old people are in need of a person who stands up for them and their problems (Jabłonka, Łęczuk 2016, p. 202). A person who can sweep away current stereotypes with their unique, remarkable personality and attitude. It stands to reason that DJ Wika fits perfectly into this role - which is why she is an unofficial ambassador of seniors in Poland.

Wirginia speaks about the problems of old people in a gutsy, direct manner - the question of low retirement pensions in Poland being one of them - but more to draw attention to the issue than to complain. She intends to show other people that in old age low or high quality of life is more a decision than a fate - "the worst is idleness. It terrifies me that some of my coevals invent diseases out of boredom, so they can visit doctors - says DJ Wika, a 73 year-old habitué of dancing-parties. [...] Unfortunately, the Polish mentality and life approach is very stereotypical. I hear people say 'what will your neighbors think of it', but I don't care. I don't do it to show 
off, I do it for myself, trying to pass my joy on - she explains. [...] She is very open-minded, also in the matter of music. Apart from the rock'n'roll classics, twist and rock, one can hear modern hits played at her parties - I like Gaga, Katy Perry and Madonna - says the 73 year-old" (Chilewicz, "Nie mam czasu na starość").

An increase in DJ Wika's popularity has certainly been triggered by the recent publication of DJ Wika jest Moc!, but there are a lot more materials on Wirginia in the mass media, for example the article by Patryk Chilewicz "I don't have time for old age", "DJ Wika is 76 years-old and shows that age is no limit!", "DJ Wika: hey men! I am only 72 years old!", "DJ Wika - the oldest Polish DJ".

Multiple articles, interviews and website sources regarding Wirginia Szmyt show her as a sensitive, open-minded, respectful person, always willing to help people (especially the old ones) and animals. She is spontaneous, full of joy and enthusiasm; courageously and stubbornly she faces adversities. She is an activist type - she likes organizing social activities and events, especially intergenerational ones.

Regardless of the emotions and feelings she stirs up (admiration, criticism, curiosity, envy), the fact that thanks to her actions old age issues have become visible in the mass media is indisputable. The following opinion confirms this: "Seniors are on top now, because she's on top. They have broken down a wall together. More seniors are getting out of home now. The $60+$ generation believes that retirement is not a limit, but a new possibility" (Easzyn 2013).

It is hard to miss the fact that during the past few years old people's issues were picked up in the political arena more often, which was followed by an increase in social activities and events aiming to improve the quality of seniors' lives. New senior-oriented entities have been formed, like the Council of Seniors, the Council of Policy for Seniors, the governmental project 'Senior-WIGOR' created by the former PM Ewa Kopacz with Wiriginia Szmyt invited to participate, or the annual Polish Senior Parade, taking place in Warsaw.

The popularity of the Senior Parade in the mass media (broadcast on TVP 2, TVN 24, TVP Info, TVP Warsaw, Superstacji, Polsat News, Radio Zet, Polish Radio Channel One, Polish Radio Channel Two and Polish Radio Channel Three) whose originator, commercial "face" and one of the ambassadors is Wirginia Szmyt, made seniors' issues and needs "visible and audible". Making old people's problems present in social life is and always has been one of the main aims of this initiative, as pointed out on 
the Foundation Zaczyn website: "the participants of the $3^{\text {rd }}$ Polish Senior Parade "Mature and Splendid" want to show that their group is growing bigger and it is becoming indispensable in order to form a consistent senior policy which in Poland was non-existant before" (http://zaczyn.org/polscyseniorzy-mistrzami-europy-czyli-o-co-chodzi-paradzie/). The great success of this event, that every year attracts more seniors and their ambassadors (famous, respected people) would not be possible if it weren't for DJ Wika, whose personality attracts not only the old people, but also younger fans.

Concluding, the mass media image of DJ Wika ranges between two different worlds. With the seniors she shares their age, experience, problems, needs and life stages - with youth, spontaneity, stamina and joy of life. For the young people the rapid development of modern technologies isn't overwhelming or surprising, nor is the music played by a DJ. Therefore, DJ Wika, familiar with the equipment, integrates these two worlds with success. She is an intergenerational bridge that unites, not divides.

Everything has another side, of course, and so does the popularity of DJ Wika. If the mass media - as Pankowska (2005) observes - plays an important role in passing on stereotypes, they can do the same to Wika's image by "turning it up" too much. There could be a possibility that her image would become the only one acceptable, a "proper" way of living life after retirement, which could have an adverse effect in some situations. What reactions and emotions may be evoked by the title of this article - "Be like DJ Wika?"? Could DJ Wika become an antiheroine?

\section{UTA Seniors opinions of DJ Wika}

Analysis of data obtained during the two focus group interviews (members' opinions and reflections) has led to the following conclusions.

First of all, DJ Wika is very popular and far-famed among seniors, thanks to her constant presence in the mass media - shows, parties, articles, interviews, etc. On the web there are lots of articles with eloquent titles: "DJ Wika more popular than Doda? A 74 year-old Wirginia Szmyt phemonenon."; "75 year-old DJ Wika breaks the stereotypes with her beats and spends her pension on discs."; "I don't have time to be old - 73 year-old DJ Wika speaks about her passion." A significant step towards even greater fame was marked by her biography, published in 2016 - this was mentioned several times by the focus group participants: (Interviewee $n^{\circ} 1$ ) "I have learnt all about her activities, parades and life from her book". (Interviewee 
$\mathrm{n}^{\circ} 2$ ): "I saw her on TV and I think she's fantastic. If only we had more people like her!". DJ Wika arouses curiosity and admiration among seniors, small wonder therefore that lots of them attend her parties and meetings: (Interviewee $n^{\circ} 1$ ) "DJ Wika had a seniors' fashion show in Arkady. Marvellous woman. I admire her greatly."

Secondly, DJ Wika causes different kinds of emotions and reactions. Some of the old people admire and respect her, whereas others criticize her lifestyle - there is also a group for whom she's irrelevant. The focus group interviewee $n^{\circ} 4$ says that Wirginia Szmyt 'is an inspiration, a great example for many seniors. I am not saying that such an intense lifestyle should be imitated in all its aspects, but people could stop making TV shows or gossiping their only hobbies [...]; (Interviewee $n^{\circ} 2$ ): "All her (Wika's) grace is in this wide smile, a bit tousled hair and that slim figure." (Interviewee $\mathrm{n}^{\circ}$ 5): "Mrs Szmyt's actions make old people think about this stage of life (old age) more carefully, leading them to some positive conclusion." (Interviewee $n^{\circ} 2$ ): "DJ Wika is a very positive person. I admire people with passions, it is always contagious. Those are the people that set trends, 'pull others up'. It's not about age. Every period of life has its own grumblers and losers. They are not always responsible for the situation they're in, but that's another story."

Where does the criticism come from, then? For whom is this lifestyle unacceptable? In the opinion of the focus group participants, the criticism comes from passive people, people unable to feel satisfaction in their lives, with an unfavorable life-balance and a sense of the low-quality of life. As interviewee $n^{\circ} 6$ points out, "She won't impress people who were different when young, and those who weren't - the curious, active, lively ones - them she might impress, and show that age is no limit for new acquaintances, dancing, travels. God bless her!".

Thirdly, DJ Wika breaks old age stereotypes. Her actions and attitude let people look at old age from a different perspective. They allow people to see its positive aspects and prompt people to keep up activity in every stage of life. Her actions and her attitude coach and teach, they influence a change in perception of old people and promote the possibility of leading various life-styles during retirement. Interviewee ${ }^{\circ} 3$ says that "She's really making a change, something important for seniors. Draws them out of home, unites them, in the parades for example, shows that despite being 70+ you can act. It's necessary and beneficial." For some seniors, DJ Wika is giving them inspiration to stay active in many areas of life - she's also considered an example worth imitating: (Interviewee $n^{\circ} 1$ ) "Yes, you can follow her example, 
definitely, pursue your dreams and passions, go out to meet other people, be cheerful, go to a party to dance, travel, realize some daring ideas - I like her lifestyle, she's sociable, kind and talkative. She makes no distinction between young and old people. I like her slim figure too (another inspiration work on myself!) and her clothes, loose and "uninhibited « - comfortable when she goes mad with her turntable. At the same time, her clothes make her look younger", (Interviewee $n^{\circ} 4$ ): "Her behaviour is worth imitating and admirable. Old age doesn't have to begloomy. If we don't become grotesque and ridiculous, then why not go crazy from time to time? Today is unrepeatable and we cannot take tomorrow for granted"' (Interviewee $n^{\circ} 6$ ): "I think it's good that this kind of person, breaking stereotypes and barriers, still exists"; (Interviewee $n^{\circ}$ 5): "It's a very positive activity, beneficial not only for her but also for the others. The young and the old people are often helpless and in need of a mentor like DJ Wika".

Fourthly, DJ Wika helps to "domesticate" old age. Her attitude fits in with the concept of good senescence (Hill, 2005: John W. Rowe, Robert L. Kahn), which renders an old age perspective free of prejudicial stereotypes and misconceptions. The focus group participants emphasise this often: (interviewee $n^{\circ} 2$ ): "I envy her spirit. I wish I could be like her in the future. I attend some classes now and do exercises, but will my strength remain?" (interviewee $\mathrm{n}^{\circ} 3$ ): "I hope there will be more people like her, she's an inspiration for other women around her age, her determination is for me an example of a nice senescence. I believe old age will affect her far later than us, although she mentioned her age complaints in the book. Her lifestyle, maybe controversial from time to time, makes old age bearable and all those events she creates draw old people out of the social shadows.". Interviewee $\mathrm{n}^{\circ} 1$ says that "Wika has always been active and open. Her personality is outstanding. She owes her success not only to her behaviour though, but also to a change in the approach towards old age. A few years ago, that woman could not have counted on social comprehension, even less acceptance"; (interviewee $n^{\circ} 7$ ): "Seniors are allowed to speak nowadays and this is multiplefaceted, too. Our social status has improved, the average life expectancy is higher thanks to the development of medicine. There are more old people still living at our age than before and we are quite fit. We have our expectations and dreams and what's important, we're willing to fulfill them and other people accept that."

Fifthly, DJ Wika integrates the generations and tears down intergenerational walls. The focus group participants emphasized this fact strongly, because in their opinion intergenerational meetings are highly valuable. They 
are a convenient platform for exchanging different views and for sweeping away prejudice, making new acquaintances and sometimes friends. Interviewee ${ }^{\circ} 5$ believes that "Wiki does useful things, she integrates the people of different ages. Deliberately or incidentally she shows young people that seniors exist and not all of them are suffering grumblers, contrary to the general opinion. The young people see old people, but cheerful, dancing ones. That went out with a bang. [...] I believe she draws her energy from the youth and give it to the seniors. In her book I read that her parties attract a lot of people of different ages. This is the time when the younger ones can see us as we are and change their perspective"; (interviewee $\mathrm{n}^{\circ} 1$ ): "We should take an example from her, how she almost stops time with her activities, how she makes us seek contacts with younger people instead of complaining about them, so they can see us as interesting in lieu of "impossible«. Let's integrate, as she does, with the youth in various areas of life."

\section{Conclusions and reflections}

Zofia Szarota points out (2010), that the current academic discussions on old age oscillate between two extreme approaches: gerontophobia (that has become ageism) and gerontocracy making its way through social policy (demands and declarations). After the analysis of DJ Wika's actions we can assume that they strengthen gerontocracy and reduce gerontophobia, evidence of this being new senior committees, the Council of Policy for Seniors and the annual Senior Parade.

The old age approach, although still entangled with stereotypes and misconceptions, in the $21^{\text {st }}$ century is gaining a new image of an active, vigorous, joyful senior. Although not predominant, let us suppose that there has been a change in experiencing, perceiving and showing old age. As Witold Jakubowski observes, "the ongoing shifts in modern societies' daily life reflect the erosion of traditional lifestyles" (Jakubowski 2011, p. 7), which in our opinion has a significant impact on old people's lifestyles, so different from those favoured in the past.

A senior experiencing the so called "third age" or "second youth" is becoming an increasingly popular image in the mass media. It is still very distant from the current and predominant image, identifying old people with diseases, dotage, loneliness and lack of activity. The "second youth" people are vigorous, creative, independent and full of energy. 
The DJ Wika phenomenon, apart from being an inspiration for our study, is an example of the mass media's more favorable attitude towards positive images of old age. At this point we must stress that her example is not the only one proving our observations to be correct. The histories of other seniors gaining popularity and fame in the mass media are likewise inspiring - there are 60+ models like Helena Norowicz (a former actor) working for Bohoboco, fashion bloggers - Barbara Bastamb (Bastamb - all about fashion and beauty), Krystyna Bałagier (fashion with a human face), Ireneusz Korzeniewski (Styleman) or the 82 year-old hitch-hiker Teresa Bancewicz. Their stories will be presented and discussed in a following article, since the current paper is the first part of a project about non-stereotypical perceptions, the experience and presentations of old age.

What makes DJ Wika so special then? The assessment of data obtained during the analysis has led us to the conclusion that her lifestyle (hobbies, passions and actions), clothing (T-shirts, colorful trousers, sneakers, headsets), attitude (frankness, "teen language", media attraction) and being a DJ constitute her "uncommon" or non-stereotypical image. Her commitment in opposing the social marginalization of seniors and her enthusiasm deserve praise as well. Wika's belief in old people's potential and capabilities is as important as her certainty that intergenerational initiatives must be taken to improve seniors' quality of life.

Our main conclusion is that DJ Wika's image is highly unorthodox. She acts in the interest of old people, bringing about a change in their social image. Wirginia Szmyt stirs up different kinds of emotion but she is mostly praised and supported, being an example of slow but constant changes in society's approach to old age.

We believe that an analysis of images of old age created and promoted in the mass media needs to be carried out and the results must be given a more detailed look as they allow us to see interesting problems and issues concerning old people, which in our view enriches gerontological studies.

\section{Bibliography}

Bois J. P. (1994), Historia starości. Od Montaigna do pierwszych emerytur, Oficyna Wydawnicza Volumen, Kraków.

Bokszański Z. (2001), Stereotypy a kultura, Monografie Fundacji na Rzecz Nauki Polskiej, Wrocław. 
Chlewiński Z. (1992), Stereotypy: struktura, funkcje, geneza. Analiza interdyscyplinarna, [w:] Chlewiński Z., Kurcz I. (red.), Stereotypy i uprzedzenia, [w:] Kolokwia psychologiczne, t. 1, Instytut Psychologii PAN, Warszawa.

Czykwin E. (2000), Białoruska mniejszość narodowa jako grupa stygmatyzowana, Wydawnictwo Uniwersyteckie Trans Humana, Białystok.

Hill D. R. (2005), Pozytywne starzenie się. Młodzi duchem w jesieni życia, Laurum, Warszawa.

Jabłonka J., Łęczuk P. (2016), DJ Wika. Jest moc!, Burda Publishing, Warszawa.

Jakubowski W. (2011), Edukacja w świetle kultury popularnej, Impuls, Kraków.

Minois G. (1995), Historia starości. Od antyku do renesansu, Marabut, Warszawa.

Nikitorowicz J. (2001), Pogranicze Tożsamość Edukacja Międzykulturowa, Trans Humana, Białystok.

Pankowska D. (2005), Wychowanie a role płóciowe, GWP, Gdańsk.

Piotrowski J. (1986), Gerontologia i geriatria, [w:] Borsowa I., Pędlich W., Piotrowski J., Rożniatowski T., Rudnicki S. (red.), Encyklopedia seniora, Wiedza Powszechna, Warszawa.

Steuden S. (2012), Psychologia starzenia się i starości, PWN, Warszawa.

Szarota Z. (2010), Starzenie się i starość w wymiarze instytucjonalnego wsparcia, Wydawnictwo Uniwersytetu Pedagogicznego, Kraków.

Straś-Romanowska M. (2000), Późna dorosłość. Wiek starzenia się, [w:] Harwas-Napierała B., Trempała J., Psychologia rozwoju człowieka. Charakterystyka okresów życia człowieka, PWN, Warszawa.

Szatur-Jaworska B., Błędowski P., Dzięgielewska M. (2006), Podstawy gerontologii społecznej, Oficyna Wydawnicza ASPRA-JR, Warszawa.

Zych A. A. (2010), Leksykon gerontologii, Impuls, Kraków.

\section{Netography}

„Młodzi duchem” - TVP3 Białystok (dostęp: 24.04.2016 Facebook)

A. Wawrzyńczak, DJ Wika - najstarsza didżejka w Polsce, dostępny na: http://kobieta.wp.pl/dj-wika-najstarsza-didzejka-w-polsce-5982683068158593a (dostęp: 26.06.2016).

P. Chilewicz., Nie mam czasu na starość - 73-letnia Dj Wika opowiada o swojej pasji, dostępny na: http://natemat.pl/26665,nie-mam-czasu-na-starosc-73-letnia-dj-wika-opowiada-o-swojej-pasji (dostęp: 26.06.2016).

I. Łaszyn, DJ Wika jest popularniejsza od Dody? Fenomen 74-letniej Wirginii Szmyt, dostępny na: http://www.dziennikbaltycki.pl/artykul/752351,dj-wika-jest-popularniejsza-od-dody-fenomen-74letniej-wirginii-szmyt,id,t.html (dostęp: 26.06.2016).

P. Szukalski, Starzenie się ludności - wyzwanie XXI wieku, dostępny na: http:// dspace.uni.lodz.pl:8080/xmlui/bitstream/handle/11089/5423/Skrypt\%20 Szukalski.pdf?sequence=1 (dostęp: 29.05.2016). 